\title{
Proportionally constant quantitative transmission of nucleolin and protein B23 in cycling cancer cells
}

\author{
V Sirri, A Pession, D Trerè, L Montanaro, M Derenzini
}

\begin{abstract}
Objective-To investigate whether and to what extent the two major AgNOR proteins, nucleolin and protein B23, are maintained after one cell division in proliferating cells.

Design-Using three asynchronously growing human cancer cell lines, TG, SJNKP, and CHP 212 cells, nucleolin and protein B23 were first identified on SDSpolyacrylamide separated nucleolar proteins, transferred to nitrocellulose and silver stained for AgNOR proteins. Measurement of doubling time indicated a period very close to $24 \mathrm{~h}$ for each of the cell lines. To quantify the percentage of nucleolin and protein B23 maintained in daughter cells after duplication, cells were labelled with $\left[{ }^{35} \mathrm{~S}\right]$-methionine and a $24 \mathrm{~h}$ cold chase performed. Nucleolin and protein B23 labelling was evaluated by densitometric analysis on nitrocellulose autoradiograms.

Results-The radioactivity relative to nucleolin and protein B23 bands maintained in the daughter cells was a constant fraction of that present before cell duplication. In the three cell lines the percentage of residual radioactivity measured in the nucleolin bands was $42 \cdot 2,40 \cdot 6$, and $41 \cdot 2$ and in protein $B 23$ bands $48 \cdot 0,46 \cdot 2$, and 44.1.

Conclusions-After one cell division the nucleolin and protein B23 quantity present in cells may be highly variable, depending on the amount of the two proteins present in the mother cell. This is important in relation to the correct utilisation of AgNOR protein quantity as an index for evaluating cell kinetics.

(f Clin Pathol: Mol Pathol 1995;48:M264-M268)
\end{abstract}

Keywords: Nucleolin, protein B23, cycling cancer cells.

In the interphase nucleolus there is a distinct set of acidic proteins which are selectively stained by methods usually used for staining the proteins associated with metaphase nucleolar organiser regions. ${ }^{1}$ The nucleolar silver stained proteins are therefore generally defined as interphase "AgNOR" proteins. In SDS gels of nucleolar proteins, demonstrated by the same silver staining procedure that is applied to cytological preparations for the selective visualisation of the AgNOR proteins, two main argyrophil bands are constantly identified at around $100 \mathrm{kDa}$ and $40 \mathrm{kDa} .^{2} \mathrm{AgNOR}$ proteins are necessary for the transcription of ribosomal genes. ${ }^{3}$ Nucleolin has been shown to induce chromatin decondensation by binding to the $\mathrm{H} 1$ histone $\mathrm{e}^{4}$ and to be associated with nascent pre-rRNA. ${ }^{5}$ Protein B23 is associated with rRNA maturation processes. In resting cells stimulated to proliferate, the amount of AgNOR proteins begins to increase during early G1 phase and reaches its greatest value at the end of $S$ phase. ${ }^{6}$ The quantitative distribution of AgNOR proteins in cancer cells is therefore used as an index of cell kinetics in tumour pathology. ${ }^{78}$

On the other hand, as far as we know, no information has been obtained about the quantitative transmission of AgNOR proteins in proliferating cells from mother to daughter cells. In fact we do not know whether after a cell division the AgNOR proteins have to be completely resynthesised or whether all the AgNOR proteins derived from the previous cell cycle are still present in the daughter cells.

This is a crucial point in relation to the use of the AgNOR protein index in tumour pathology since in tumour lesions in vivo some of the cancer cells are not continuously dividing but have left the cycle after division. In this case the quantity of AgNOR proteins transmitted from the previous cell cycle may no longer reflect the actual kinetic activity of the cells. To ascertain whether and to what degree AgNOR proteins are transmitted to the daughters of cycling cells we have evaluated the quantitative transmission of the two main AgNOR proteins, nucleolin and protein B23, in three human cancer cell lines.

For this purpose, we first identified nucleolin and protein B23 in nucleolar proteins separated on SDS gels and transferred to nitrocellulose membrane, using the silver staining procedure according to Hozák et al. ${ }^{9}$ Then we measured the percentage of nucleolin and protein B23 transmitted after cell duplication to the daughter cells by $\left[{ }^{35} \mathrm{~S}\right]$-methionine protein labelling.

\section{Methods}

CELL CULTURE

The three cell lines used in this study were derived from human tumours: CHP 212 and SJNKP cell lines were from neuroblastomas; the TG cell line was from a tubal carcinoma. All cell lines were maintained as monolayer cultures in RPMI 1640 medium, supplemented with non-essential amino acids, $100 \mathrm{U} / \mathrm{ml}$ of penicillin, $100 \mu \mathrm{g} / \mathrm{ml}$ of streptomycin, and $10 \%$ fetal calf serum (FCS). Cells were incubated at $37^{\circ} \mathrm{C}$ in a humidified atmosphere of $5 \%$ $\mathrm{CO}_{2}, 95 \%$ air. 
CELL DOUBLING TIME MEASUREMENT

Inocula of $5 \times 10^{5}$ cells were grown in plastic flasks and the cell doubling times were determined by counting the asynchronously growing cells in triplicate samples at 24,36 , and $48 \mathrm{~h}$ intervals according to the methods described by Patterson. ${ }^{10}$ Cell doubling times were also measured by means of $\left[{ }^{3} \mathrm{H}\right]$-thymidine incorporation. Three flasks of each cell line were labelled for $30 \mathrm{~min}$ with $0.5 \mu \mathrm{Ci} / \mathrm{ml}$ of $\left[{ }^{3} \mathrm{H}\right]$-thymidine (specific activity $25 \mu \mathrm{Ci} / \mathrm{mmol}$ ) and used as controls; three other flasks were labelled in the same way for $30 \mathrm{~min}$, washed with RPMI 1640 containing $1 \mathrm{mM}$ cold thymidine, and cultured for $24 \mathrm{~h}$ in RPMI 1640 supplemented with non-essential amino acids, $100 \mathrm{U} / \mathrm{ml}$ of penicillin, $100 \mu \mathrm{g} / \mathrm{ml}$ of streptomycin, and $10 \%$ FCS. For the evaluation of DNA incorporation, cells were collected from the flasks in cold phosphate buffered saline (PBS) containing $1 \mathrm{mM}$ thymidine and centrifuged for $10 \mathrm{~min}$ at $1500 \mathrm{~g}$. Pellets were resuspended in PBS and acid precipitated with $0.6 \mathrm{~N}$ perchloric acid. Pellets were treated with $0.3 \mathrm{~N} \mathrm{KOH}$ to solubilise RNA, and after washing twice with $0.2 \mathrm{~N}$ perchloric acid, DNA was extracted with $7 \%$ perchloric acid for $15 \mathrm{~min}$ at $70^{\circ} \mathrm{C} .^{11} \mathrm{DNA}$ quantity was estimated according to Burton. ${ }^{12}$ The radioactivity of DNA samples was measured after addition of scintillation fluid (Read Gel, Beckman).

DETECTION OF INDIVIDUAL AGNOR PROTEINS For each cell line, cells were collected, washed in PBS, and lysed at $4^{\circ} \mathrm{C}$ in TKM buffer (10 mM Tris- $\mathrm{HCl} \mathrm{pH} \mathrm{7.4,} 10 \mathrm{mM} \mathrm{KCl}, 3 \mathrm{mM}$ $\mathrm{MgCl}_{2}$ ) containing $0 \cdot 1 \%$ Triton X-100, $1 \mathrm{mM}$ PMSF, $10 \mu \mathrm{g} / \mathrm{ml}$ aprotinin, $1 \mu \mathrm{g} / \mathrm{ml}$ pepstatin, and $1 \mu \mathrm{g} / \mathrm{ml}$ leupeptin. The nuclear pellets were then washed twice with $0.25 \mathrm{M}$ sucrose in TKM buffer. Nucleoli were prepared by sonication of the isolated nuclei (15 s cycle and $15 \mathrm{~s}$ pause at $70 \mathrm{~W}$ ). The nucleolar pellets were washed with $0.88 \mathrm{M}$ sucrose in TKM buffer, suspended in Laemmli sample buffer, ${ }^{13}$ boiled for $5 \mathrm{~min}$, and centrifuged for $30 \mathrm{~s}$. The protein concentration of each sample was determined according to the method described by Lowry ${ }^{14}$ using serum albumin as standard. Samples of nucleolar proteins $(15 \mu \mathrm{g})$ were electrophoresed in $10 \%$ SDS-polyacrylamide gels. Size standards from 200 to $29 \mathrm{kDa}$ (Sigma) were included in each gel. Polypeptides were electrotransferred to reinforced cellulose nitrate membranes (BA-S 85, Schleicher and Schuell) which were then cut into strips. For AgNOR protein detection, the membranes were stained in plastic culture dishes. The membranes were pretreated twice with $20 \%$ ethanol for $10 \mathrm{~min}$ and the silver staining method with gelatin colloidal developer, selective for AgNOR proteins, was used as previously described. ${ }^{9}$

QUANTITATIVE ANALYSIS OF NUCLEOLAR PROTEINS CONSERVED AFTER A CELL CYCLE Protein synthesis of the CHP 212, SJNKP, and TG cell lines was evaluated by incubating cells in a RPMI 1640 medium without methionine containing $60 \mu \mathrm{Ci} / \mathrm{ml}$ of $\left[{ }^{35} \mathrm{~S}\right]$-methionine. Medium with labelled methionine was added to flasks for $6 \mathrm{~h}$; after the incubation time half of the cells were collected and used to evaluate the level of amino acid incorporation into the proteins. The other half of the cells were left in culture for another $24 \mathrm{~h}$, in a medium containing cold methionine, and then collected. To measure the level of radioactivity in the individual nucleolar proteins, SDS-PAGE-separated nucleolar proteins were transblotted on nitrocellulose membranes as previously described for AgNOR protein detection. Nitrocellulose membranes were exposed on a $\beta$ MAX Hyperfilm (Amersham). For image acquisition of the autoradiographic signals an EPSON GT 8000 scanner was used. In-

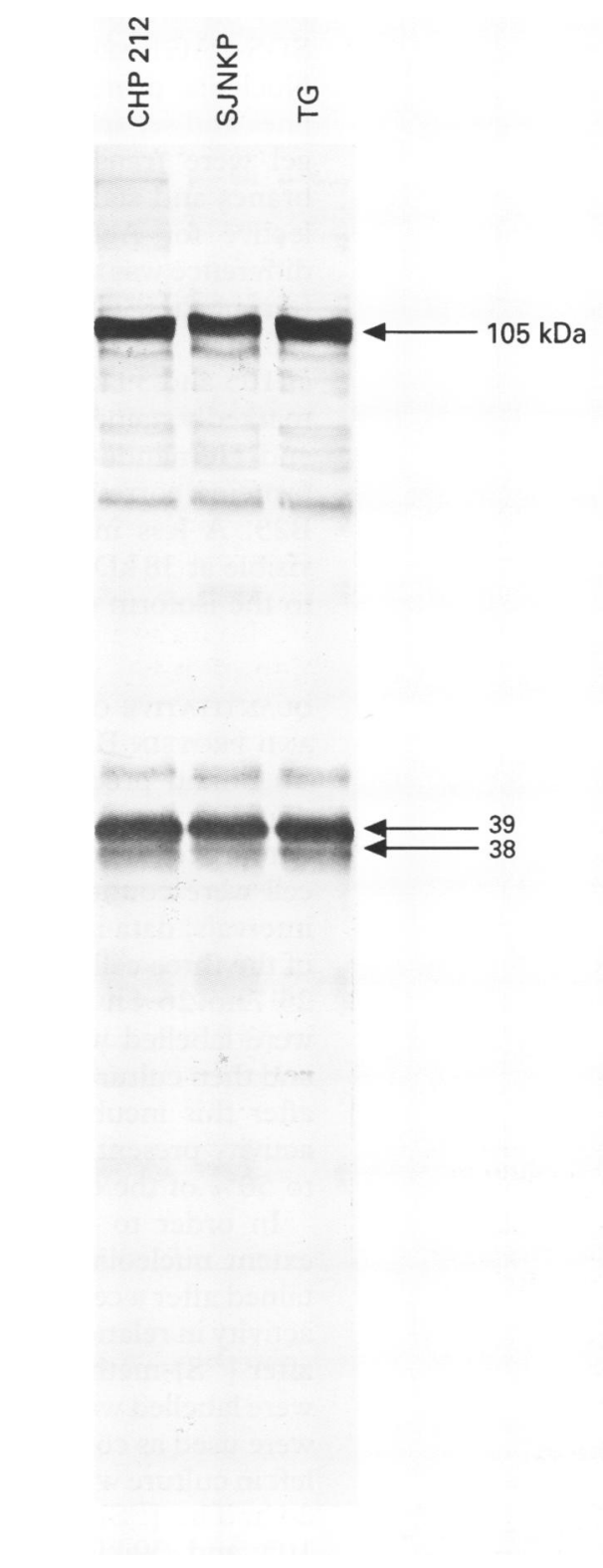

Figure 1 AgNOR staining on nitrocellulose membrane. The nucleolar proteins extracted from the three cell lines (CHP 212, SFNKP, TG) after SDS-polyacrylamide gel separation have been transferred to nitrocellulose membrane and stained by the silver staining procedure according to Hozák et al. ${ }^{9}$ Only a few proteins are stained. The major positive bands correspond to polypeptides at 105, 39, and $38 \mathrm{kDa}$. 
Population doubling time. Values are means (SD)

\begin{tabular}{|c|c|c|c|}
\hline & \multirow[b]{2}{*}{$\begin{array}{l}\text { Counting } \\
\text { method (hours) }^{a} \text { ) }\end{array}$} & \multicolumn{2}{|c|}{${ }^{3} \mathrm{H}$-thymidine labelling } \\
\hline & & Control & 24 hour chase \\
\hline $\begin{array}{l}\text { CHP } 212 \\
\text { SJNKP } \\
\text { TG }\end{array}$ & $\begin{array}{l}23 \cdot 7 \\
24 \cdot 1 \\
26 \cdot 4\end{array}$ & $\begin{array}{l}770(125) \\
662(152) \\
758(-92)\end{array}$ & $\begin{array}{l}351(50) \\
289(22) \\
378(39)\end{array}$ \\
\hline
\end{tabular}

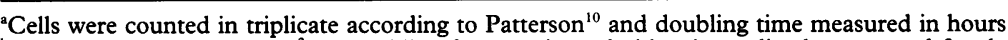
${ }^{6}$ Cells were incubated with ${ }^{3} \mathrm{H}$-thymidine for $30 \mathrm{~min}$ and either immediately processed for the evaluation of DNA labelling by ${ }^{3} \mathrm{H}$-thymidine (control) or incubated without addition of ${ }^{3} \mathrm{H}-$ thymidine for $24 \mathrm{~h}$ and then processed ( $24 \mathrm{~h}$ chase). Radioactivity is expressed in dpm/ $\mu \mathrm{g}$ DNA.

corporation of $\left.{ }^{35} \mathrm{~S}\right]$-methionine in the protein bands was quantified by measuring the peak area of the densitometric tracings. The Gel Image System (Pharmacia) was employed.

\section{Results}

IDENTIFICATION OF NUCLEOLIN AND PROTEIN

B23 ON NITROCELLULOSE TRANSFERRED

SDS-PAGE SEPARATED NUCLEOLAR PROTEINS

Nucleolar proteins extracted from the three cell lines and separated on an SDS-polyacrylamide gel were transferred to nitrocellulose membranes and stained with the silver method selective for AgNOR proteins. No significant difference was observed in the distribution pattern of the AgNOR proteins among the three cell lines (fig 1). In each line, two polypeptides at 105 and $39 \mathrm{kDa}$, respectively appeared to be markedly stained by silver. As shown by Roussel and Hernandez-Verdun, ${ }^{15}$ these silver stained proteins correspond to nucleolin and protein B23. A less intensely stained band was also visible at $38 \mathrm{kDa}$. This appeared to correspond to the isoform of protein B23.

\section{QUANTITATIVE CONSERVATION OF NUCLEOLIN AND PROTEIN B23}

To obtain precise information about the cell doubling time of the three cell lines two different procedures were employed: (1) growing cell were counted in triplicate at regular time intervals; data indicated that the doubling time of the three cell lines was similar, ranging from 23.7 to $26.4 \mathrm{~h}$ (table); (2) the three cell lines were labelled with $\left[{ }^{3} \mathrm{H}\right]$-thymidine for $30 \mathrm{~min}$ and then cultured for $24 \mathrm{~h}$ with cold thymidine; after this incubation time the residual radioactivity present in the DNA ranged from $44 \%$ to $50 \%$ of the control values (table).

In order to evaluate whether and to what extent nucleolin and protein B23 were maintained after a cell cycle, we measured the radioactivity in relation to the 105 and $39 \mathrm{kDa}$ bands after $\left[{ }^{35} \mathrm{~S}\right]$-methionine labelling. Growing cells were labelled with $\left[{ }^{35} \mathrm{~S}\right]$-methionine for $6 \mathrm{~h}$ : half were used as controls while the remainder were left in culture with cold methionine for a further $24 \mathrm{~h}$. The $\left[{ }^{35} \mathrm{~S}\right]-$ methionine incorporation into 105 and $39 \mathrm{kDa}$ proteins was evaluated by densitometric analysis on autoradiographic tracings (fig 2). After $6 \mathrm{~h}$ of incorporation the peak area corresponding to 105 and $39 \mathrm{kDa}$ proteins showed values of 0.15 and 0.55 for CHP 212 cells, 0.21 and 0.51 for SJNKP cells, and 0.14 and 0.55 for TG cells. The autoradiographic tracings corresponding to the

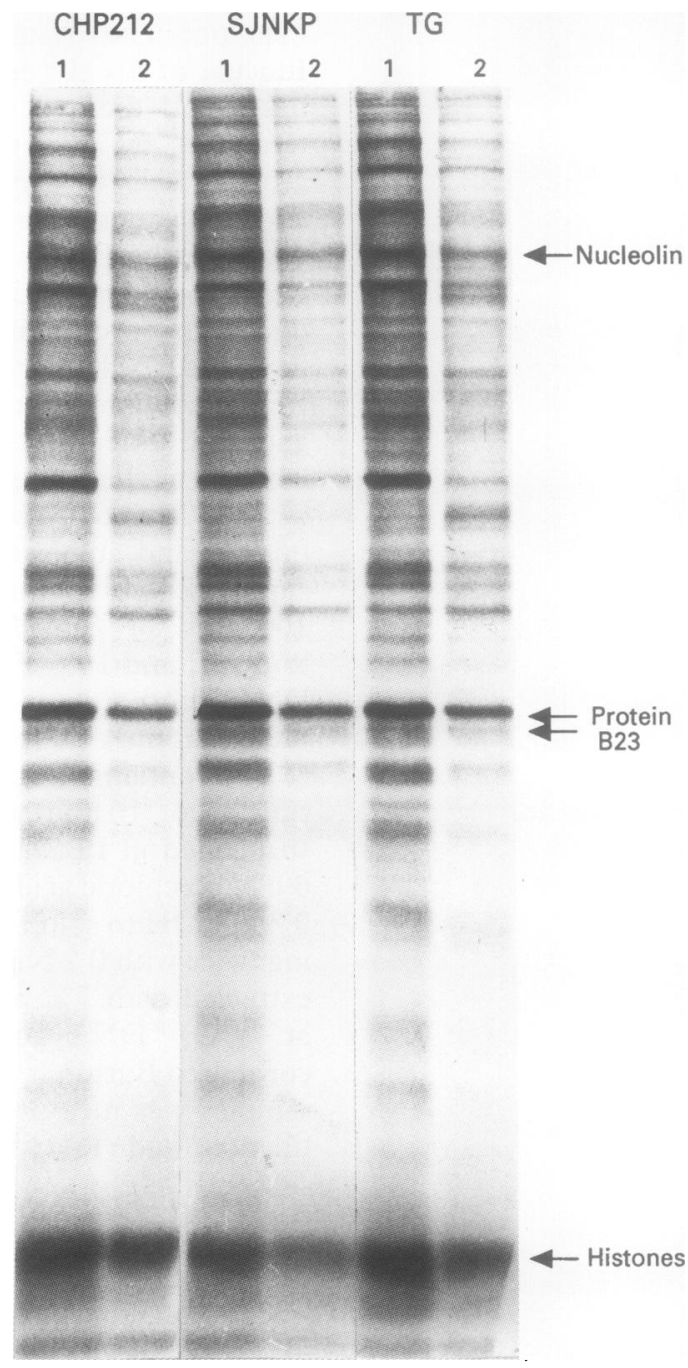

Figure 2 Autoradiography of SDS-PAGE separated nucleolar proteins transblotted on nitrocellulose membrane. The three cell lines, CHP 212, SÆNKP, and TG, have been labelled for $6 h$ with $\left.{ }^{35} S\right]-m e t h i o n i n e$, then half of the cells (lanes 1) were collected for nucleolar protein extraction and half were left in culture for another $24 \mathrm{~h}$ (anes 2) in a medium containing cold methionine. After this time the cells were collected for nucleolar protein extraction.

$\left[{ }^{35} \mathrm{~S}\right]$-methionine still present in the cells after $24 \mathrm{~h}$ showed that the area corresponding to 105 and $39 \mathrm{kDa}$ proteins was 0.065 and 0.27 for CHP 212 cells, 0.09 and 0.25 for SJNKP cells, and 0.06 and 0.25 for TG cells. Measurement of autoradiographic tracings relative to $\left[{ }^{35} \mathrm{~S}\right]$-methionine incorporation into histones, still present after $24 \mathrm{~h}$, indicated that the radioactivity maintained in the three cell lines was fairly constant, ranging from $51 \%$ to $53 \%$ of control values.

\section{Discussion}

Our results have shown that, in proliferating cells, the two main AgNOR proteins, nucleolin and protein B23, are transmitted to the daughter cells and the quantity transmitted is a constant fraction of the amount of the two proteins present in the mother cells.

Identification of nucleolin and protein B23 was obtained using nitrocellulose transblotted SDS-PAGE-separated proteins from purified nucleoli of three cancer cell lines stained by the 
silver method selective for AgNOR proteins. ${ }^{9}$ Only two bands, at 105 and $39 \mathrm{kDa}$ respectively, were markedly stained. Silver staining of SDS-PAGE-separated nucleolar proteins has constantly revealed bands around $100 \mathrm{kDa}$ and $40 \mathrm{kDa}^{2}{ }^{2}$ Roussel and Hernandez-Verdun ${ }^{15}$ showed that in western blots of SDS-PAGEseparated nucleolar proteins from $\mathrm{CHO}$ cells two polypeptides of $105 \mathrm{kDa}$ and $39 \mathrm{kDa}$ were stained by a silver method specific for AgNOR proteins. The identification of these two major silver stained bands as nucleolin and protein B23 was demonstrated recently in western blots using antibodies and purified proteins. ${ }^{16}$ It is therefore reasonable to conclude that the silver stained nucleolar proteins at $105 \mathrm{kDa}$ and $39 \mathrm{kDa}$ correspond to nucleolin and protein B23.

The quantity of $105 \mathrm{kDa}$ and $39 \mathrm{kDa}$ proteins which remained in the three cell lines after one cell cycle was then evaluated. In order to do this we first determined the doubling time of the three cell lines by counting the cells at regular time intervals ${ }^{10}$ and also measured the residual radioactivity of previously incorporated $\left[{ }^{3} \mathrm{H}\right]$-thymidine. Using the counting procedure the doubling time ranged from $23 \cdot 7$ to 26.4 hours and the evaluated quantity of radioactivity relative to $\left[{ }^{3} \mathrm{H}\right]$-thymidine ranged from $44 \%$ to $50 \%$ of that present in the three cell lines 24 hours previously. These data taken together show that the doubling time of the three cell lines was very close to the time (24 hours) determining the quantity of nucleolin and protein B23 left after a cell cycle using $\left[{ }^{35} \mathrm{~S}\right]$-methionine labelling. This was also supported by the finding that the radioactivity present in the histone band (histones are transmitted in a semiconservative way) ranged from $51 \%$ to $52 \%$ of that present 24 hours before. The quantity of radioactivity remaining after 24 hours and relative to $\left[{ }^{35} \mathrm{~S}\right]$-methionine incorporated into the $105 \mathrm{kDa}$ and $39 \mathrm{kDa}$ proteins of the three cell lines ranged, respectively, from $42 \%$ to $43 \%$ and from $45 \%$ to $49 \%$, of that measured in the previous cell generation. These values showed that the quantity of nucleolin transmitted from mother to daughter cells was similar in the three cell lines, and the same was also true for protein B23.

The quantity of AgNOR proteins can be used as an index in the evaluation of cell kinetics in routine cytological or histological preparations of tumours. ${ }^{78}$ Cancer cells are characterised by a higher quantity of AgNOR proteins than the corresponding hyperplastic and normal tissues, ${ }^{17}$ and the quantitative distribution of AgNOR proteins is directly related to the state of cancer cell proliferation. ${ }^{78}$ The fact that after division a cell maintains the quantity of AgNOR proteins which is related to the previous proliferating activity independent of whether the cell will divide again casts some doubt on the validity of the evaluation of cell kinetics of tumours by quantification of the mean AgNOR protein. Measurement of the mean AgNOR protein value in tumour sections might not precisely reflect the cell kinetic activity of all cancer cells, since some might have left the cell cycle and yet still have a high AgNOR protein quantity "inherited" from the previous cell cycle. However, this drawback can be eliminated by measuring the coefficient of variation (CV) relative to the AgNOR protein value. The $\mathrm{CV}$ value is influenced by the standard deviation, which in turn is influenced by the different content of AgNOR proteins in proliferating cells. Indeed, the quantity of AgNOR proteins increases progressively when the cell enters the mitotic cycle, from the $G_{1}$ to the $S$ phase. ${ }^{6}$ Therefore, the $\mathrm{CV}$ relative to the AgNOR protein content can indicate the proliferation state of cancer cells, whatever the quantity of AgNOR proteins present in the cell at the beginning of the cycle and "inherited" from the previous cell cycle.

The present data are also interesting as far as the relationship between AgNOR protein quantity and cell doubling time is concerned. Cell proliferation is conditioned by the synthesis of the substances necessary for progression through the mitotic cycle and a suitable quantitative ribosomal biogenesis is its prerequisite. Accumulation of nucleolin in adult bovine aortic endothelial cells stimulated by basic fibroblastic growth factor has been reported to precede the increase of rDNA transcription. ${ }^{18}$ As far as protein B23 is concerned, after receptor mediated induction of cellular proliferation by various mitogens the synthesis of this protein increases rapidly at early G1 phase. However, cell activation in relation to stimuli which do not induce synthesis of DNA fails to stimulate the synthesis of protein B23. ${ }^{19}$ It appears therefore that the synthesis of these proteins represents a crucial event occurring very early after mitogenic signals. ${ }^{20} \mathrm{~A}$ different quantitative availability of these proteins at early $\mathrm{G} 1$ phase could control cell proliferation in continuously dividing cells such as cancer cells. The fact that the quantity of nucleolin and protein B23 transmitted to the daughter cells is a constant fraction of the amount of these proteins synthesised during the previous cell cycle may represent an important factor for maintaining the cell duplication time constant, for a continuously dividing cell line.

This work was supported by grants from Ministero della Università e della Ricerca Scientifica e Tecnologica (MURST) $40 \%$ and $60 \%$, Pallotti's Legacy for Cancer Research, Regione Emilia-Romagna (DGR 4243/1991) and AIRC (Milan).

1 Howell WM. In: Busch H, Rothblum L, eds. The cell nucleus, vol 11. New York: Academic Press, 1982:89-142.

2 Olson MOJ. In: Straus PR, Wilson SH, eds. The eukaryotic nucleus, vol 2. New York: Telford Press, 1990:519-59.
non

3 Miller OJ, Miller DA, Dev VG, Tantravahi R, Croce CM Expression of human suppression of mouse nucleolus organizer activity in mouse-human somatic cell hybrids. Proc Natl Acad Sci USA 1976;73:4531-5.

4 Erard MS, Belenguer P, Caizergues-Ferrer F, Pantaloni A, Almaric F. A major nucleolar protein, nucleolin, induces chromatin decondensation by binding to histone H1. Eur f Biochem 1988;175:525-30.

5 Herrera AH, Olson MOJ. Association of protein C23 with rapidly labelled nucleolar RNA. Biochemistry 1988;25: 6258-64.

6 Pession A, Farabegoli F, Treré D, Novello F, Montanaro $\mathrm{L}$, Sperti S, et al. The Ag-NOR proteins and transcription and duplication of ribosomal genes in mammalian cell nucleoli. Chromosoma 1991;100:242-50.

7 Derenzini $M$, Ploton D. Interphase nucleolar organizer regions in cancer cells. Int Rev Exp Pathol 1991;32:150-92. 8 Derenzini M, Treré D. Importance of interphase nucleolar organizer regions in tumor pathology. Virchows Arch B 1991;61:1-8.

9 Hozák P, Roussel P, Hernandez-Verdun D. Procedure for specific detection of silver-stained nucleolar proteins on western blots. $\mathcal{F}$ Histochem Cytochem 1992;40:1089-96. 
10 Patterson MJ. Measurement of growth and viability of cell culture: in: Jokoby WB, Pastan IH, eds. Methods in en-
zymology, vol 58. New York: Academic Press, 1979:14152 .

11 Montecuccoli G, Novello F, Stirpe F. Effect of $\alpha$-amanitin poison on the synthesis of deoxyribonucleic acid of protein in regenerating rat liver. Biochim Biophys Acta 1973;319. 199-207.

12 Burton B. A study of the condition and mechanism of the diphenylamine reaction for the colorimetric estimation of deoxyribonucleic acid. Biochem f 1956;62:315-33.

13 Laemmli UK. Cleavage of structural proteins during the assembly of the heat of bacteriophage $\mathrm{T}_{4}$. Nature 1970 ; 227:680-5.

14 Lowry OH, Rosebrough NJ, Farr AL, Randall RJ. Protein measurement with the folin phenol reagent. 7 Biol Chem 1951;193:265-75.

15 Roussel P, Hernandez-Verdun D. Identification of Ag-NOR proteins, markers of proliferation related to ribosomal gene activity. Exp Cell Res 1994;214:465-72.
16 Roussel P, Sirri V, Hernandez-Verdun D. Quantification of Ag-NOR proteins using Ag-NOR staining on Western
blots. 7 Histochem Cytochem $1994 ; 42: 1513-7$.

17 Crocker J. Nucleolar organizer regions. Curr Top Pathol 1990;82:91-149.

18 Bouche G, Gas N, Prats H, Baldin V, Tauber JP, Teissie J, et al. Basic fibroblast growth factor enters the nucleolus and stimulates the transcription of ribosomal genes in ABAE cells undergoing G0-61 transition. Proc Natl Acad Sci USA 1987;84:6770-4.

19 Feuerstein N, Chan PK, Mond JJ. Identification of numatrin, the nuclear matrix protein associated with induction of mitogenesis, as the nucleolar protein B23. F Biol Chem 1988;263:10608-12.

20 Feuerstein N, Spiegel S, Mond JJ. The nuclear matrix protein, numatrin (B23), is associated with growth factor protein, numatrin (B23), is associated with growth factor
induced mitogenesis in Swiss 3Ts fibroblasts and with T lymphocytes proliferation stimulated by lectins and by lymphocytes proliferation stimulated by lectins and by
anti T-cell antigen receptor antibody. $\mathcal{F}$ Cell Biol 1988; 107:1629-42. 